\title{
WHAT ISN'T REMEMBERED
}

\section{How to be alone.}

\section{BY HIROMI GOTO}

$\mathrm{T}$ he laptop is whirring. Somewhere inside the machine, the little man has turned on the fan to cool down the engine. Outside, the rain falls in slow heavy strands. The day is saturated and it's not even noon. The rusty eavestrough, filled with years of debris, just pours a steady stream out of a crack onto the concrete below. The persistent splatter sounds like someone is frying a dozen eggs in a cast-iron frying pan. My stomach groans.

"There, there," I pat my stomach as if it's an old dog. "Some day. Some day."

Gerry Rafferty dead 50 years ago today I input Baker Street and the soft blue-purple glow around his '70s face, the croon of the sax riff, bring a surge of tears to my eyes. His beautiful voice tinged with wabi sabi, and his last drink always the very last one. The year he died, high definition was the rage. I prefer the soft focus of memory's natural erosion.

I opted out long ago on expanding my personal hard drive. I don't regret my choice. It's actually meant a monthly allowance owing to my disability: my function capability is rated so low that if I were a fetus, I'd be quickly modified or humanely disconnected before the end of the first trimester. Hah!

The children feel shame about my status. Have they deleted their memories of me? It's several years since Corona last visited. I think it's been several years. I don't keep a journal. No one needs a calendar anymore because it's in their head. People used to tell the overwrought, the neurotic ones that. "It's all in your head!" Now it's digitally true. Hahahahahaaaa!

The wellness monitor bleats from the ceiling. Capable of detecting CO, natural gas, even 'excessive' testosterone, it's a sound of concern. A reminder. A warning. If I had a shotgun I'd blast it to pieces.

If my children don't remember me, am I still a mother?

Their neural networks are connected to everyone, everything. Filters exist but they are cosmetic. Secrets are deemed asocial; only the suspect has anything to hide, so the Glory Of All People imprints as soon as data neurons are activated. My children accused me of being asocial - a technophobe NeoNostalgic Luddite.

Dear children - technology did not frighten me. What I didn't want to lose were my own brain's idiosyncratic ways of forgetting.

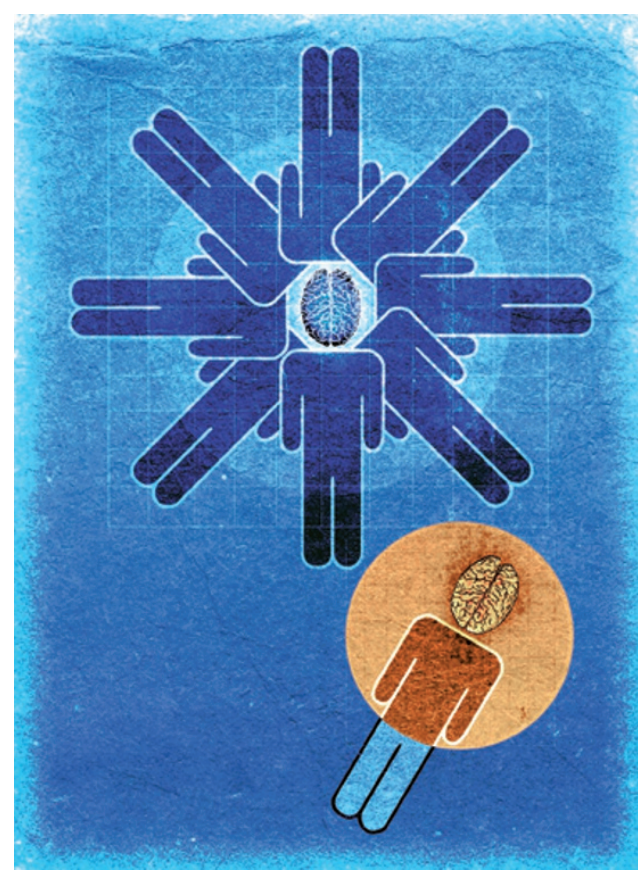

Delete the undesirable data, they said, eyes vacant as their augmented minds streamed far more than my grey matter could ever imagine.

Dear children - what worlds your eyes have seen, your mortal mother will never comprehend. And I am okay with that.

When was Baker Street released? 1978 ... Sniff'n' the Tears, Cat Stevens, all those ballads. The old heart squeezes with a sweet bruise pain. Fleeting, like a first good wine.

Whatever happened to me in 1978, all I have left is this whiff of something slightly bitter, but indescribably sweet. A forgetting remembered in an ephemeral language.

There is a qualitative difference between deleting and forgetting.

What about all those important things that were lost? asked Corona, who was always logical, even before augmentation became the basic. Countless languages gone extinct. Genetic code of plants, animal, fungi, microbes. Corona always spoke slowly, as if I couldn't keep up. Mind, she probably had terabytes of streaming data while she spoke to me in complete sentences.

Data can be lost, corrupted. Systems fail, crash, empires tumble, civilizations dis- $\rightarrow$ NATURE.COM

Follow Futures on

Facebook at:

go.nature.com/mtoodm

\section{appear.}

That's why we have the Glory, but we must always back up, Corona said gently.
When she speaks with her own kind they are like Butoh dancers. Their shared networks streaming, their vacant faces sometimes contorting, a single word dropping from their lips like a small sculpture from an ancient civilization.

I know I've made myself a curiosity, but I don't regret my choices. I sleep very well at night.

You won't need to sleep anymore, Corona explained.

I love sleeping.

The fried-egg splatter of rain has morphed into the sizzling of French fries. What I wouldn't do for some fries! No one's allowed to eat them any more; no health benefits for the Glory Of All People. A lot of things have no benefits.

If you augment, Corona said, the last time she visited, you can enjoy French fries all you like. You won't be able to tell the difference. Experience is neurotransmissions. If you augment you can have all your pleasures, but none of the consequences. She even managed a semblance of a smile.

My daughter, I love you more than French fries. I love you more than sleeping, I love you more than Right Down the Line. But I will not augment.

Corona modified my old laptop, buffering it against the overload of data it would never be able to access. The buffer functions like a beaver dam, so just a thin trickle can reach me, to keep me company in my chosen isolation.

My body is old. I still enjoy my sleep, but it's been a very long time since I've eaten French fries.

My friends have all gone, downloaded into Glory. But I will not. I've left my brain to the Morbid Anatomy Library and Cabinet where my mindvelt can only be experienced by the visitor as a discrete and fleeting download. It will be set up to work only if she has turned off all of her other networks. I want to leave a trace of what it once felt like to be alone.

I hope that the cabinet where my brain will be housed is labelled with a small card. Let them write with a fountain pen on antique paper, at least $100 \mathrm{lbs}$, matte finish.

Forget. .

Hiromi Goto has won the Tiptree, Sunburst and Carl Brandon Parallax Award among others. Her dark fantasy novel, Darkest Light, will be published in spring 2012 with Penguin Canada. www.hiromigoto.com. 